Article

\title{
Re-Os Geochronology and Sulfur Isotopes of the Lyangar W-Mo Deposit: Implications for Permian Tectonic Setting in South Tianshan Orogen, Uzbekistan
}

\author{
Zhen-Ju Zhou ${ }^{1,2}$, Zheng-Le Chen ${ }^{1,2,3, *(\mathbb{D})}$, Bakhtier Nurtaev ${ }^{4}\left(\mathbb{0}\right.$, Shukhrat Shukurov ${ }^{4}$, \\ Feng-Bin Han ${ }^{1,2}$, Zong-Xiu Wang ${ }^{1,2}$, Wei-Feng Xiao ${ }^{1,2}$ and Xin-Qi Yu ${ }^{5}$ \\ 1 Laboratory of Dynamic Diagenesis and Metallogenesis, Institute of Geomechanics, Chinese Academy of \\ Geological Sciences, Beijing 100081, China \\ 2 Key Laboratory of Paleomagnetism and Tectonic Reconstruct, Ministry of Natural Resources, \\ Beijing 100081, China \\ 3 State Key Laboratory of Nuclear Resources and Environment, East China University of Technology, \\ Nanchang 330013, China \\ 4 Institute of Geology and Geophysics, Tashkent 100041, Uzbekistan \\ 5 School of the Earth Sciences and Resources, China University of Geosciences (Beijing), Beijing 100029, China \\ * Correspondence: chenzhengle@mail.cgs.gov.cn
}

Received: 19 July 2019; Accepted: 30 August 2019; Published: 1 September 2019

\begin{abstract}
The Lyangar W-Mo skarn deposit is located in the Nuratau area (western Uzbekistan), South Tianshan Orogen. The skarn system is distributed along the contact zone between the Aktau granitoid and the upper Paleozoic sedimentary rocks. Six molybdenite samples from the Lyangar deposit yielded a Middle Permian Re-Os isochron age of 268.0 $\pm 12.0 \mathrm{Ma}(\mathrm{MSWD}=0.43$ ) and a weighted mean age of $263.8 \pm 1.5 \mathrm{Ma}(\mathrm{MSWD}=0.22)$. Molybdenites have low Re contents (12.49 to $16.65 \mathrm{ppm}$ ), indicative of a continental crust-dominated source. The molybdenite $\delta^{34} \mathrm{~S}$ values fall inside a narrow range ( 1.0 to $3.8 \%$; average $2.3 \%$ o), implying that the ore metals were likely derived from the granite intrusion. We concluded that the Lyangar W-Mo deposit was formed in a post-collisional setting caused by continental collision between the Tarim and Kazakhstan cratons.
\end{abstract}

Keywords: Lyangar W-Mo deposit; molybdenite Re-Os ages; sulfur isotopes; skarn; south Tianshan orogen

\section{Introduction}

Tungsten (W) skarn deposits host the world's principal W resource, many with high grades and large tonnages [1]. The largest $\mathrm{W}$ mineral provinces in the world include South China, Central Europe, Southeast Asia, Western Canada, and East Australia [2,3]. Located in the southern part of the Central Asia Orogenic Belt (CAOB; [4]), the South Tianshan Orogen experienced a long-lived arc-basin evolution, and finally took shape through late Paleozoic collision between the Tarim and Kazakhstan-Yili blocks [5]. The region is favorable for hydrothermal mineralization of various types, according to the petrogenic and metallogenic models of oceanic plate subduction [6-10] and continental collision [7,8,11-17]. Many mineral occurrences were discovered in the South Tianshan Orogen (e.g., $\mathrm{Au}, \mathrm{W}, \mathrm{Hg}, \mathrm{Sb}, \mathrm{Pb}$, and $\mathrm{Zn}$ ), including some world-class orogenic-type gold deposits (e.g., Muruntau, Amantaitau, Daugyztau, and Zarmitan; [18-21]), large Al deposits (Boruhskoe and Hodgaachkan), together with large W-Sn (Trudovoe) and W (Meliksu and Kumysh-Tash) deposits [22,23]. In the Uzbekistan South Tianshan Orogen, four W-(Mo) deposits have been discovered, i.e., Ingichko, Lyangar, Yahton, and Sautbay, but their ages and tectono-metallogenic setting are still unclear [24]. 
Molybdenite Re-Os geochronology can be used to as a powerful tool to determine the age of mineralization $[25,26]$. Isotopic compositions of the ore sulfides provide insights into the nature and source of the ore-forming fluids [7,27-32]. The Lyangar W-Mo deposit is representative in the Nuratau area (western Uzbekistan) of the South Tianshan Orogen. Previous studies reveal that the skarn orebody presents along the contact zone between the Aktau intrusion and the lower Paleozoic sedimentary rocks [24]. However, no reliable age data have been reported for the deposit. This paper reports new molybdenite Re-Os and S isotopic data of the Lyangar W-Mo deposit, and thereby discusses the source of ore-forming fluids, and constrains the age of mineralization and tectonic setting of the deposit.

\section{Regional Geology}

The Tianshan Orogen, which extends for over $2000 \mathrm{~km}$ from the Aral Sea to Xinjiang in NW China, constitutes an important component of the Central Asian Orogenic Belt (CAOB; Figure 1A; [3,4,33]). The Tianshan Orogen comprises three tectonic units, i.e., (from north to south) Northern Tianshan, Central Tianshan, and Southern Tianshan. These units are bounded by the North Tianshan, Nikolave Line-North Nalati, Atbashi-Inlychek-South Nalati, and the North Tarim faults, respectively (Figure 1B; [34-36]). The South Tianshan Orogen took shape through continental collision between the Tarim and Kazakhstan-Yili blocks [5].

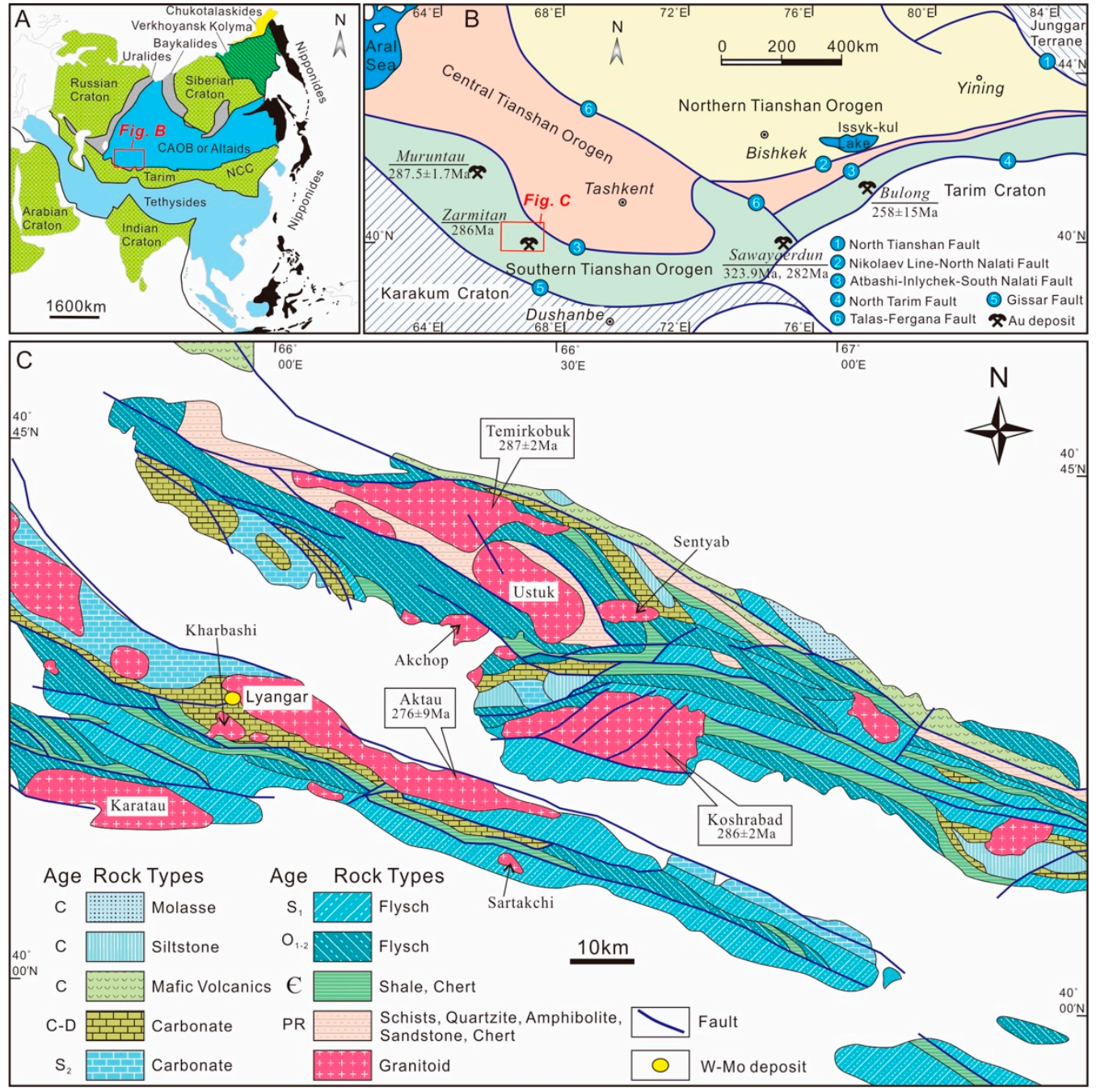

Figure 1. (A) Schematic tectonic map of Asia, showing the location of South Tianshan Orogen (modified after [4]). (B) Tectonic map of the South Tianshan Orogen and adjacent regions (modified after [35]). (C) Geologic map of the Nuratau area (modified after [18]). Abbreviations: NCC = North China Craton. 
The Nuratau area is located in the western part of the South Tianshan Orogen (Figure 1B), and geologically comprises mainly Meso-Neoproterozoic and Paleozoic successions [18]. Meso-Neoproterozoic rocks consist of schists, quartzite, amphibolite, sandstone, and chert. The Cambrian sequences mainly include greenschist- to amphibolite-facies metamorphosed siltstone, carbonaceous shale, chert, and minor dolomite. The unconformably-overlying Ordovician-Lower Silurian flysch sequences comprise of shale, siltstone, and sandstone interbeds. These sequences are unconformably overlain by thick Devonian-Carboniferous carbonate rocks [18], which are in turn overlain by Carboniferous molassic sequences.

These aforementioned lithostratigraphic units are intruded by late Paleozoic granitoids, such as the Aktau and Koshrabad complexes [18,37]. These granitoids occur as northwest-elongated plutons, parallel to the major regional structures (Figure 1C; [18]), suggesting a structural control on the granitoid emplacement. The available zircon $\mathrm{U}-\mathrm{Pb}$ ages show that the granitoids are predominantly early Permian (ca. 287-276 Ma; [37]), coeval and possibly associated with the late Paleozoic collision between the Tarim and Kazakhstan-Yili blocks in the South Tianshan Orogen [4,18,37,38].

\section{Deposit Geology}

The Lyangar deposit is located in the southern Nuratau area (Figure 1). The ore hosts include mainly the Lower Devonian and Carboniferous sedimentary rocks [24] (Figure 2). The Lower Devonian Bahiltau Formation consists mainly of limestone and marble. These rocks are highly fractured and are interpreted to be favorable for the ore-fluid migration. The Carboniferous Darasay Formation comprises mainly shale and sandstone. Orebodies at Lyangar are hosted in the garnet skarn zone between Aktau intrusion and these upper Paleozoic sedimentary rocks (Figure 2).

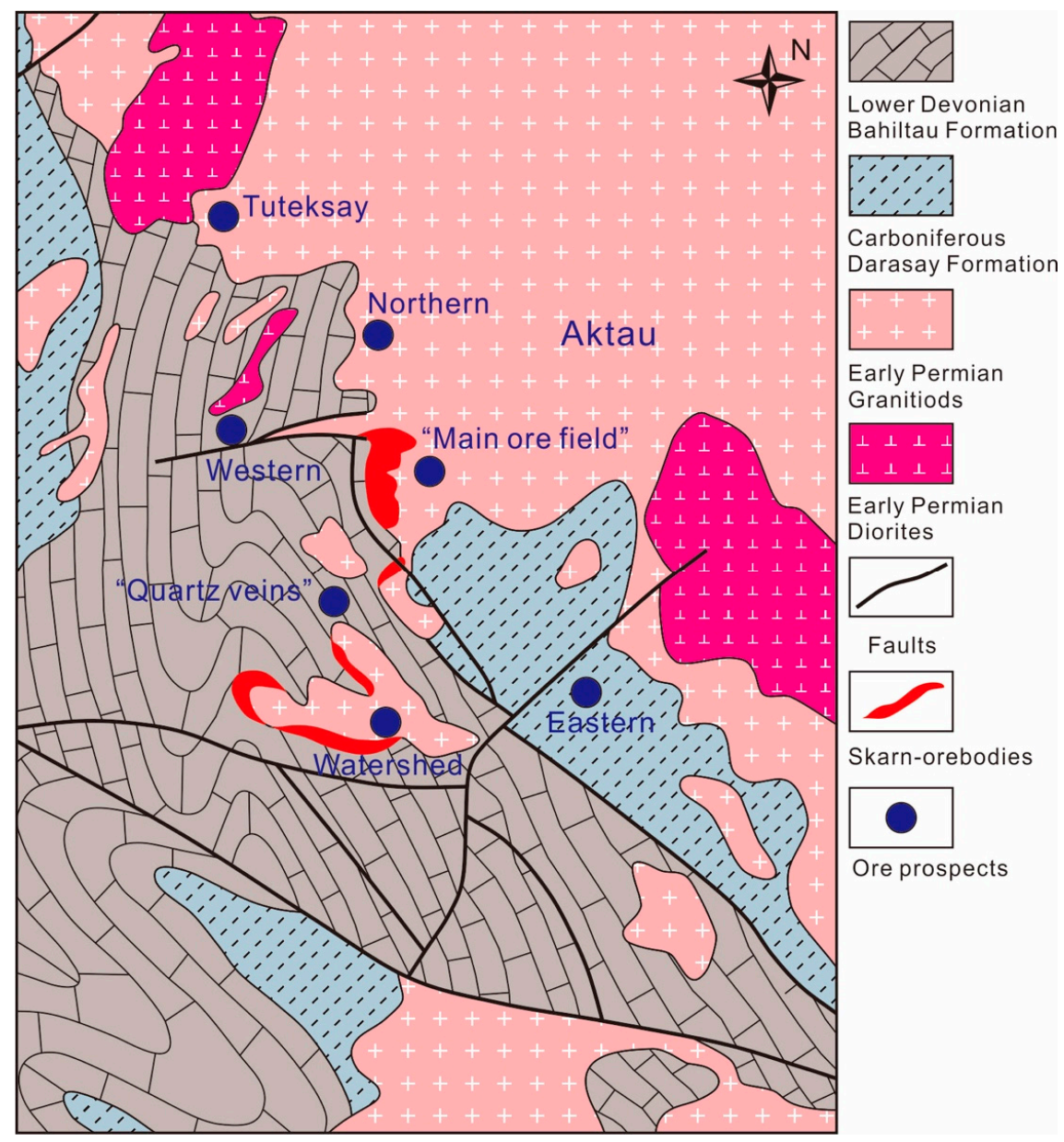

Figure 2. Simplified geologic map of the Lyangar W-Mo deposit (modified after [24]). 
Magmatic rocks at Lyangar include the south-western parts of the Aktau pluton, which comprises mainly biotite granite, granodiorite, and adamellite, among which the former is closely W mineralization related. The intrusive contact is commonly gentle $\left(10-35^{\circ}\right)$ and discordant (Figure 2$)$. Alteration styles include albite, silicic, and muscovite alterations. Seltmann et al. [37] reported a SHRIMP zircon U-Pb of $276 \pm 9 \mathrm{Ma}$ for the Aktau granite.

Skarn alteration minerals include mainly garnet, diopside, scapolite, epidote, and wollastonite (Figure 3A). The intrusive contact zone varies from a few hundred meters to 1-1.5 km wide.
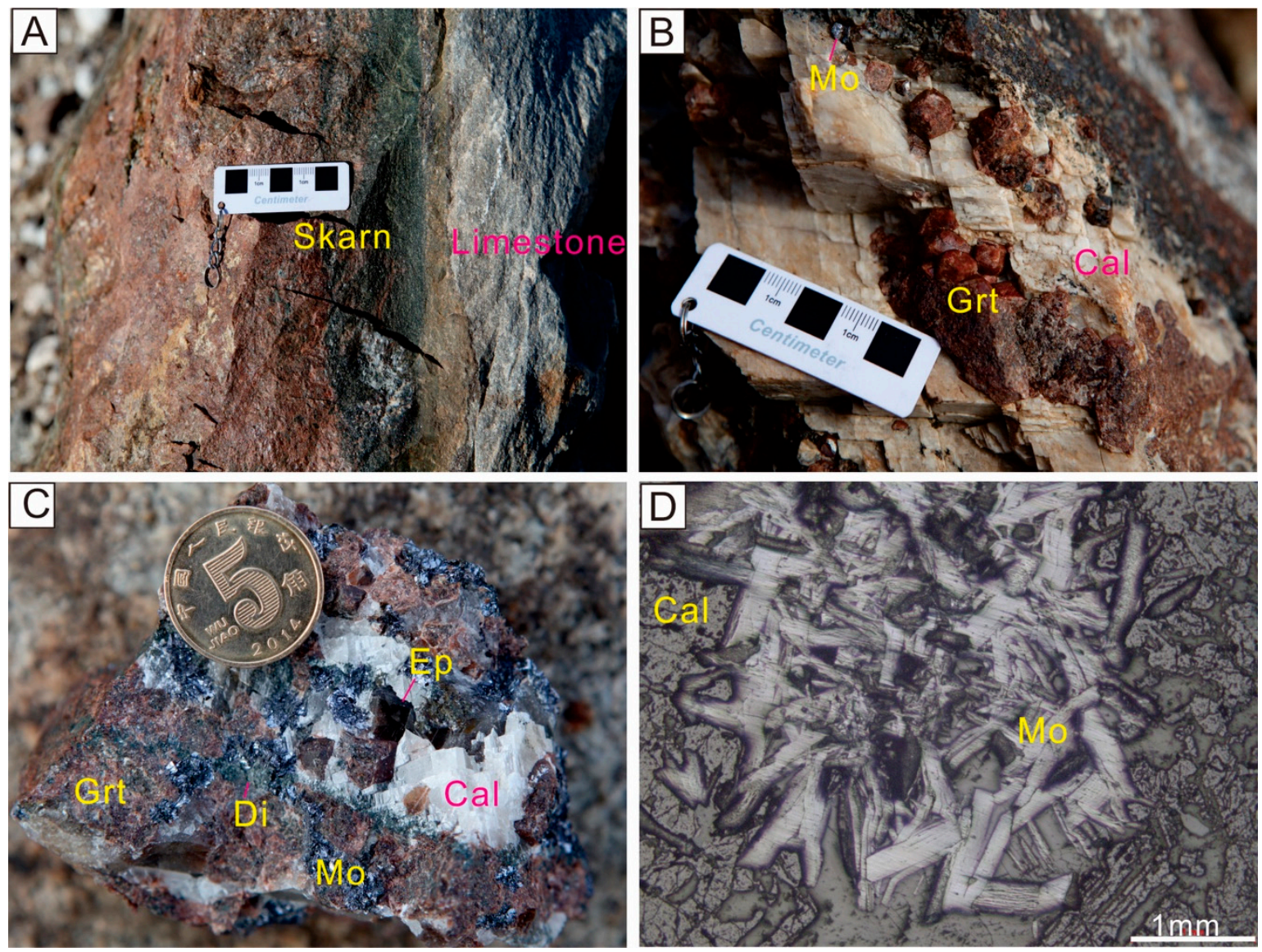

Figure 3. Field and thin section photos of the Lyangar W-Mo deposit. (A) skarn in the contacts to limestone; (B) coarse-grained, euhedral-subhedral garnet; (C) coarse-grained epidote and molybdenite aggregates; and (D) molybdenite displaying flakes or films texture. Abbreviations: Cal = calcite; $\mathrm{Mo}=$ molybdenite; Grt = garnet; Di = Diopside; Ep = epidote.

The medium-sized Lyangar skarn W-Mo deposit includes seven W-Mo prospects being discovered so far (Figure 2). Among these seven prospects, the "Main Orefield" hosts the majority of the ore reserves. Individual orebodies are 5 to $40 \mathrm{~m}$ thick and up to $500 \mathrm{~m}$ long, with depths continue to at least $400 \mathrm{~m}$. The ore grades vary from $0.1 \%$ to $2 \% \mathrm{WO}_{3}$ [24]. The orebodies occur as nest-like and tabular bodies (Figure 2). Ore minerals include mainly scheelite and molybdenite, and minor pyrite, pyrrhotite, chalcopyrite, arsenopyrite, sphalerite, bismuthinite, and gold. Non-metallic minerals include mainly skarn minerals (e.g., garnet and diopside), epidote, quartz, and calcite (Figure 3). Garnet from Lyangar is dominated by euhedral to subhedral and coarse-grained (generally up to $1 \mathrm{~cm}$ ), which have oscillatory zoned form (Figure 3B,C). Diopside is subhedral to anhedral, up to $5 \mathrm{~cm}$ long and $0.05-2 \mathrm{~cm}$ wide (Figure $3 \mathrm{C}$ ). The epidote is euhedral to subhedral with varying sizes $(0.05-6 \mathrm{~mm})$ (Figure 3C). Calcite is commonly coarse-grained $(0.05-5 \mathrm{~cm})$ (Figure 3B). Molybdenite appears as disseminated flakes or aggregates (Figure 3C) or films (Figure 3D). 


\section{Analytical Methods}

\subsection{Molybdenite Re-Os Isotope Analysis}

Molybdenite were separated from the ore samples using pincers and then crushed into 40-60 mesh. After panning and filtering, inclusion-free molybdenite grains were picked under a binocular microscope. The molybdenite separates were digested using $\mathrm{HCl}$ and concentrated $\mathrm{HNO}_{3}$ in a sealed Carius tube and equilibrated with ${ }^{185} \mathrm{Re}$ and ${ }^{190}$ Os spikes [39]. Osmium was distilled as $\mathrm{OsO}_{4}$ from the matrix, and rhenium was separated from the remaining solution by solvent extraction and cation exchange resin chromatography. The Re and Os contents in the samples were determined by the isotopic dilution assay method. The Re-Os isotope ratios were performed on a TJA X-series ICP-MS manufactured by the Thermo Electron Corporation, Waltham, MA, USA, at the Re-Os Laboratory of the National Research Center of Geoanalysis in Beijing, using the methods outlined by Du et al. [40]. The analytical reliability was tested using reference material GBW04435 (JDC). Re-Os isochron and weighted mean calculations were made using Isoplot [41], with a ${ }^{187} \operatorname{Re}$ decay constant of $1.666 \times$ $10^{-11} /$ year.

\subsection{Sulfur Isotopes}

Molybdenite grains were extracted from the samples through conventional techniques including crushing, oscillation, heavy liquid, and magnetic separation, and were selected by handpicking under a binocular microscope (purity $>99 \%$ ). Sulfur isotopes analyses were conducted on a MAT253 continuous flow isotope ratio mass spectrometer (Thermo Electron Corporation, Waltham, MA, USA) coupled to an elemental analyzer (EA-IRMS, Thermo Electron Corporation, Waltham, MA, USA) at the State Key Laboratory of Ore Deposit Geochemistry, Institute of Geochemistry, Chinese Academy of Sciences. The powders of molybdenite were packed in tinfoil, and converted into purified $\mathrm{SO}_{2}$ for sulfur isotopic analysis under a vacuum and high temperature $\left(\sim 1000{ }^{\circ} \mathrm{C}\right)$ conditions. Sulfur isotope compositions are expressed using $\delta^{34} \mathrm{~S}$ value in per mil (\%o) relative to the Vienna Canyon Diablo Troilite standard (V-CDT), with an analytical precision of $\pm 0.2 \%$. Sulfur isotopic data are calibrated by international standard samples GBW-4414 $\left(\mathrm{Ag}_{2} \mathrm{~S}, \delta^{34} \mathrm{~S}=-0.07 \%\right.$ o $)$ and GBW-4415 $\left(\delta^{34} \mathrm{~S}=22.15 \%\right.$ o $)$.

\section{Results}

\subsection{Molybdenite Re-Os Isotopes}

The analytical data on Re-Os isotope of six molybdenite samples from Lyangar are presented in Table 1 and illustrated in Figure 4. The molybdenite ${ }^{187}$ Re and ${ }^{187}$ Os contents are $12.49-16.65$ ppm and 34.36-46.11 ppb, respectively. These samples yielded individual Re-Os isotope model ages from $262.2 \pm 3.8 \mathrm{Ma}$ to $264.8 \pm 3.6 \mathrm{Ma}(2 \sigma)$. This gave an isochron age of $268.0 \pm 12.0 \mathrm{Ma}(\mathrm{MSWD}=0.43$ ) and an initial ${ }^{187} \mathrm{Os} /{ }^{188} \mathrm{Os}$ of $-0.5 \pm 1.8$ (Figure $4 \mathrm{~A}$ ). The extremely low initial ${ }^{187} \mathrm{Os} /{ }^{188} \mathrm{Os}$ ratios (near zero), indicate that the Re-Os ages are reliable and can represent the crystallization age of molybdenite. The weighted mean age for all the molybdenite samples is $263.8 \pm 1.5 \mathrm{Ma}$ (MSWD $=0.22$; Figure $4 \mathrm{~B}$ )

Table 1. Molybdenite Re-Os isotopic data for the Lyangar W-Mo deposit.

\begin{tabular}{|c|c|c|c|c|c|c|c|c|c|c|c|}
\hline \multirow[t]{2}{*}{ Sample } & \multirow{2}{*}{$\begin{array}{l}\text { Weight } \\
\text { (g) }\end{array}$} & \multicolumn{2}{|c|}{$\begin{array}{c}\operatorname{Re} \\
(\mathbf{p p m})\end{array}$} & \multicolumn{2}{|c|}{$\begin{array}{c}\text { Common Os } \\
(p p b)\end{array}$} & \multicolumn{2}{|c|}{$\begin{array}{l}{ }^{187} \operatorname{Re} \\
(\mathrm{ppm})\end{array}$} & \multicolumn{2}{|c|}{$\begin{array}{l}{ }^{187} \mathrm{Os} \\
\text { (ppb) }\end{array}$} & \multicolumn{2}{|c|}{$\begin{array}{l}\text { Model Age } \\
\text { (Ma) }\end{array}$} \\
\hline & & Measured & $2 \sigma$ & Measured & $2 \sigma$ & Measured & $2 \sigma$ & Measured & $2 \sigma$ & Age & $2 \sigma$ \\
\hline L1-5 & 0.020 & 13.96 & 0.10 & 0.18 & 0.02 & 8.77 & 0.06 & 38.79 & 0.24 & 264.8 & 3.6 \\
\hline L1-6 & 0.011 & 13.30 & 0.09 & 0.15 & 0.06 & 8.36 & 0.06 & 36.85 & 0.25 & 264.1 & 3.6 \\
\hline L1-7 & 0.012 & 14.96 & 0.120 & 0.04 & 0.05 & 9.40 & 0.08 & 41.39 & 0.30 & 263.7 & 3.8 \\
\hline L1-8 & 0.011 & 16.65 & 0.13 & 0.04 & 0.04 & 10.47 & 0.08 & 46.11 & 0.32 & 263.8 & 3.7 \\
\hline L1-9 & 0.011 & 12.49 & 0.10 & 0.06 & 0.03 & 7.85 & 0.06 & 34.36 & 0.25 & 262.2 & 3.8 \\
\hline L1-12 & 0.015 & 14.48 & 0.12 & 0.15 & 0.03 & 9.10 & 0.08 & 40.16 & 0.29 & 264.3 & 3.9 \\
\hline
\end{tabular}



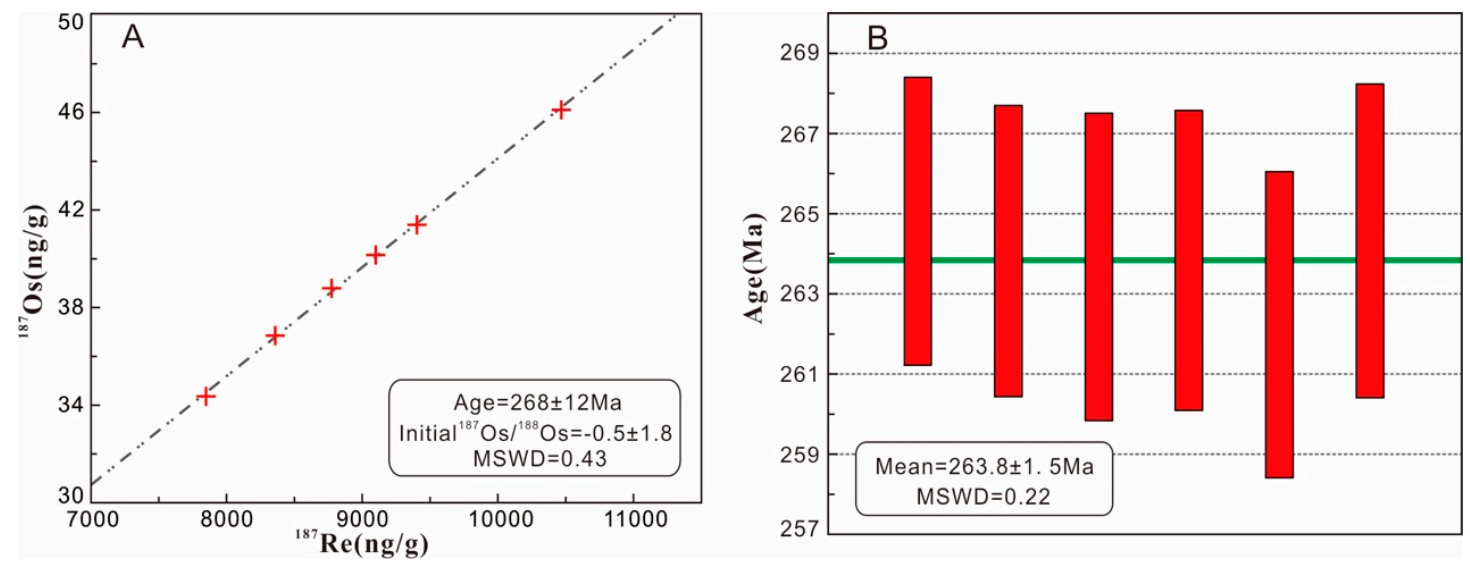

Figure 4. Isochron (A) and weighted mean ages (B) of molybdenite from the Lyangar W-Mo deposit.

\subsection{Sulfur Isotopic Compositions}

Sulfur isotope compositions of molybdenite for the Lyangar ores are presented in Table 2. The molybdenite $\delta^{34} \mathrm{~S}$ values fall into a narrow range $(1.0-3.8 \%$, average $2.3 \%$ o). This isotopic homogeneity of the Lyangar molybdenite suggests a single reservoir or common source for the ore-forming fluids.

Table 2. The $\delta^{34} \mathrm{~S}$ values of molybdenite from the Lyangar ores.

\begin{tabular}{ccc}
\hline No. & Sample No. & $\boldsymbol{\delta}^{34}$ S $_{\text {VCDT }} \% \mathbf{o}$ \\
\hline 1 & L1-5 & 3.8 \\
2 & L1-6 & 1.0 \\
3 & L1-7 & 2.1 \\
4 & L1-8 & 1.6 \\
5 & L1-9 & 1.9 \\
6 & L1-10 & 3.8 \\
7 & L1-11 & 1.2 \\
8 & L1-12 & 2.6 \\
& Average & $2.3 \pm 1.1$ \\
\hline
\end{tabular}

\section{Discussion}

\subsection{Timing of Mineralization}

The Aktau granite, main $\mathrm{W}$ ore-related intrusive rocks at Lyangar, was SHRIMP zircon U-Pb dated to be $276 \pm 9 \mathrm{Ma}$ [37]. This age is largely coeval (within error) with the molybdenite Re-Os isochron age $(268.0 \pm 12.0 \mathrm{Ma})$. Thus, the Aktau granite and the $\mathrm{W}$ mineralization have a close temporal and probably genetic link.

\subsection{Source of Ore-Forming Components}

Contents of Re in molybdenite from various hydrothermal deposits show a large variation from ppm to percent, and can be used to determine the ore-forming material source and tectonic setting $[25,42,43]$. In general, the molybdenites from the mantle and/or subducted oceanic crust generally contain higher Re contents $\left(n \times 10^{2} \mathrm{ppm}\right)$ than those from the continental crustal rocks $(n-n$ $\times 10 \mathrm{ppm} ;[25,42,44-46])$. The Re contents in molybdenite from Lyangar vary from 12.49 to $16.65 \mathrm{ppm}$ (average $14.31 \mathrm{ppm}$; Table 1), which are comparable to those of many W-Mo skarn deposits in NW China, such as Xiaoliugou (6.23-14.87 ppm; [47]) and Xiaobaishitou (40.33-64.67 ppm; [3]) in which the ore-forming materials were inferred to be derived mainly from the continental crust. 
The molybdenite $\delta^{34} \mathrm{~S}$ values of the Lyangar ores range from $1.0 \%$ o to $3.8 \%$, similar to those of the average granitic rocks (ca. $-2 \%$ o to $8 \%$; [48]), indicating a magmatic sulfur source. Considering the close relationships between the granitic rocks and the Lyangar W-Mo deposit (Figures 2 and 3), the Aktau granitic rocks were likely a significant source of ore metals in the development of the Lyangar orebodies.

\subsection{Mineralization and Tectonic Setting}

In the late Paleozoic, many types of metallic deposits were formed in the South Tianshan Orogen and were associated with intensive granitic magmatism [49-51]. In Uzbekistan, Mörelli et al. [52] obtained arsenopyrite Re-Os isochron age of 287.5 \pm 1.7 Ma for the Muruntan orogenic gold deposit, and Goldfarb et al. [21] reported pyrite Re-Os age of $286 \mathrm{Ma}$ for the Zarmitan orogenic gold deposit. In NW China, Zhang et al. [35] reported pyrite Re-Os isochron ages of 323.9 $\pm 4.8 \mathrm{Ma}$ and $282 \pm 12 \mathrm{Ma}$ for the Sawayaerdun orogenic gold deposit, Zhao et al. [53] obtained quartz Rb-Sr isochron age of 258 $\pm 15 \mathrm{Ma}$ for the Bulong Ba-Au deposit, and Li and Chen [54] reported quartz Rb-Sr isochron age of $265 \pm 12$ Ma for the Huoshibulake Mississippi Valley Type (MVT) Pb-Zn deposit. The molybdenite Re-Os isochron age (268 $\pm 12 \mathrm{Ma})$ from Lyangar is similar to these $\mathrm{Au}-\mathrm{Pb}-\mathrm{Zn}$ mineralization ages, and suggests that late Paleozoic time was a significant metallogenic period in South Tianshan Orogen.

Tectonic setting of the Early to Middle Permian South Tianshan Orogen is still debated to be syn-/post-collisional [5,37,55-58]) or continental arc setting before the final South Tianshan Ocean closure [59-61]. The 298-260 Ma post-collisional granitoids have been found in the South Tianshan Orogen, which are mainly characterized by A-type, calc-alkaline I-type, and minor S-type rocks [5,37], as exemplified by the granitoids at North Tamdinsky (287.5-293.3 Ma; [62]), Aktau (276 \pm 9 Ma; [37]), Altyntau (281 \pm 2 Ma; [37]), Dzhizlan-Chatti (293 \pm 5 Ma; [37]), Temirkobuk (287 \pm 2 Ma; [37]), Gatcha (281 \pm 1 Ma; [37]), and Koshrabad (286 \pm 2 Ma; [37]) in Uzbekistan, Karavshuy (259-267 Ma; [63]), Inylchek (268 \pm 8 Ma; [64]), Uchkoshkon (273-279 Ma; [57,64]), Djangart (296 Ma; [58,65]), Mudrym (281 \pm 2 Ma; [57]), and Kok-Kiya (281 $\pm 3 \mathrm{Ma}$; [57]) in Kyrgyzstan, and Heiyingshan (285 \pm 4 Ma; [66]) and Baleigong (273-291 Ma; [67-69]) in China. Gao et al. [5] reported a zircon U-Pb age of $285 \pm$ $2 \mathrm{Ma}$ for an undeformed granite dyke crosscutting high-pressure (HP) metamorphic units in the Chinese South Tianshan Orogen, which constrains the upper time limit for the HP metamorphism. It is interpreted that these late Paleozoic (298-260 Ma) deposits and coeval magmatic rocks (Figure 1), were both formed in the post-collisional extension and thinning caused by the Tarim-Kazakhstan continent-continent collision (Figure 5).

The Lyangar W-Mo deposit is temporally and genetically related to the Aktau intrusive rocks. Geochemical characteristics of the Aktau granite at Lyangar suggest that it belongs to high-K calc-alkaline I-type rocks occurred in a post-collisional environment [70]. H-O-C isotopic data indicate that the ore-forming fluids mainly drive from magmatic-hydrothermal fluids, and the limestone is at least a source of ore metals [70]. Furthermore, our Re-Os and S isotope data also support the interpretation that the Lyangar deposit is magmatic hydrothermal associated with the emplacement of the Aktau granite.

The Molybdenite from the Lyangar W-Mo shows mineralization ages of 268.0 $\pm 12.0 \mathrm{Ma}$. Similar mineralization events have been reported in South Tianshan Orogen, including orogenic gold deposit, MVT deposit (Figure 1B) [21,35,52-54], related to post-collisional tectonism. Integrating ore geology, geochronology and S isotope data, we conclude that the Lyangar W-Mo deposit was a skarn-type system formed in the Tarim-Kazakhstan collision setting as illustrated in Figure 5. During the post-collision between the Tarim and Kazakhstan cratons in Permian, lithospheric extension and thinning resulted in the partial melting of the continental curst, and generated widespread development of granitic magmatism [56,71,72]. These magmatic fluids migrated upward and provided numerous ore-forming metals such as W, Mo. Hydrothermal fluids could fill and replace the metals from the upper Paleozoic sedimentary rocks (e.g., limestone), and then formed Lyangar W-Mo orebodies. 


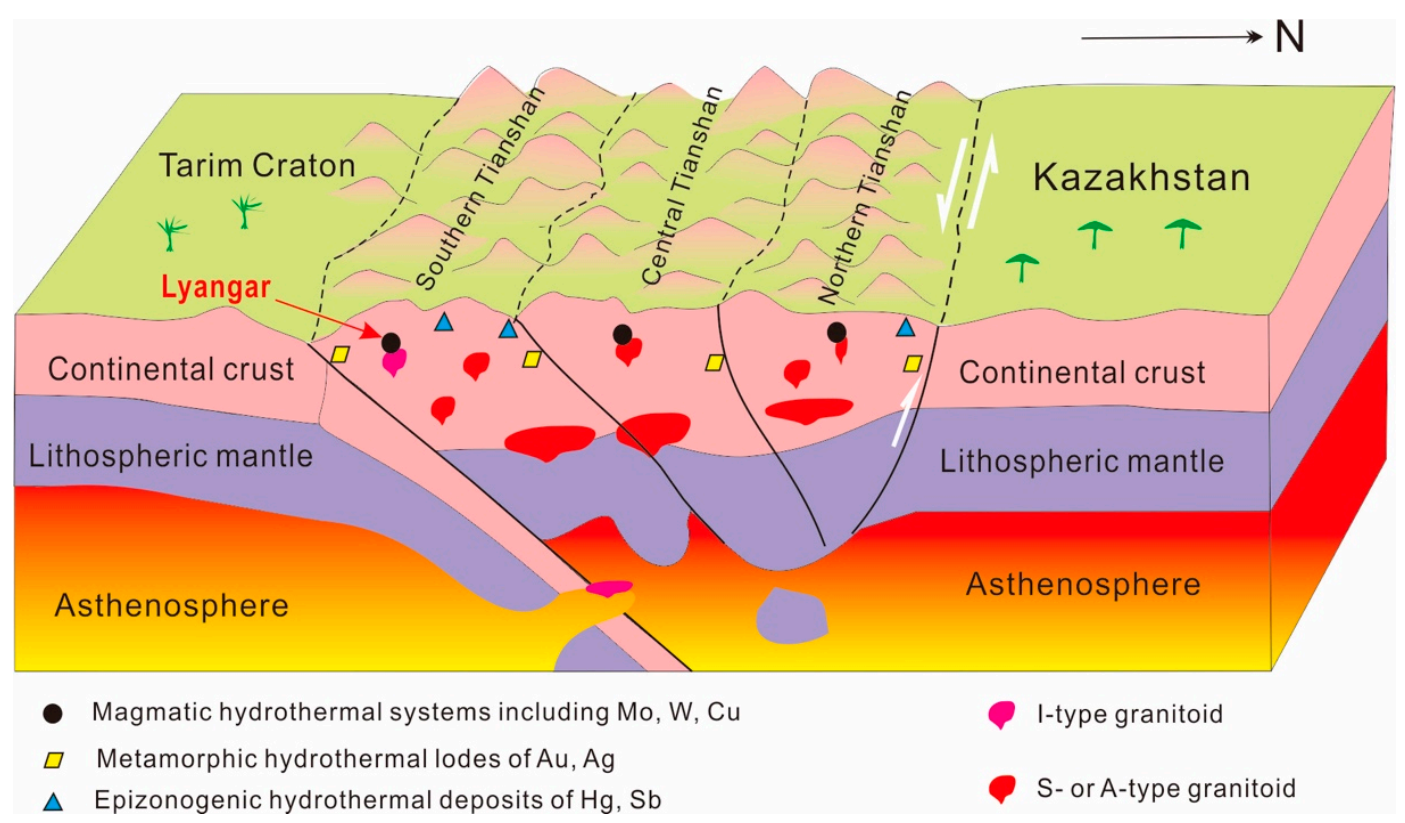

Figure 5. Schematic diagram for the tectono-magmatic-metallogenic setting in Permian South Tianshan Orogen (Base map modified after [3]).

\section{Concluding Remarks}

(1) Molybdenite grains from the Lyangar W-Mo deposit are characterized by low Re contents (12.49-16.65 ppm), and the $\delta^{34} \mathrm{~S}$ values cluster between $1.0 \%$ and $3.8 \%$. This suggests that the ore-metals dominantly originated from the continental crust, probably from the Aktau granitic magmatism.

(2) Molybdenite from the Lyangar W-Mo deposit yielded a Permian Re-Os isochron age of $268.0 \pm$ 12.0 Ma, which represents the timing of the Lyangar W-Mo mineralization.

(3) The Lyangar W-Mo mineralization likely occurred in a post-collisional setting related to the late Paleozoic Tarim-Kazakhstan collision.

Author Contributions: Field sampling and data analysis, Z.-J.Z., Z.-L.C., B.N., S.S., F.-B.H., Z.-X.W., W.-F.X., X.-Q.Y.; Original draft preparation, Z.-J.Z., Z.-L.C.; Manuscript discussion, Z.-J.Z., Z.-L.C., W.-F.X., B.N.; Manuscript review and editing, Z.-J.Z., Z.-L.C.

Funding: This work was jointly granted by the National Natural Science Foundation of China (Nos. 41772085, U1403292, 41402061), National Key Technology Research and Development Program of the Ministry of Science and Technology of China (2018YFC0604005, 2015BAB05B04), and the China Geological Survey Bureau (1212011120335, 12120114006201).

Acknowledgments: We thank Jing Gu for the sulfur isotope experiment, and Chao Li for his assistance with molybdenite Re-Os dating.

Conflicts of Interest: The authors declare no conflict of interest.

\section{References}

1. Meinert, L.D.; Dipple, G.M.; Nicolescu, S. World skarn deposits. Econ. Geol. 2005, 100, 299-336.

2. Romer, R.L.; Kroner, U. Phanerozoic tin and tungsten mineralization-Tectonic controls on the distribution of enriched protoliths and heat sources for crustal melting. Gondwana Res. 2016, 31, 60-95. [CrossRef]

3. Deng, X.H.; Chen, Y.J.; Santosh, M.; Wang, J.B.; Li, C.; Yue, S.W.; Zheng, Z.; Chen, H.J.; Tang, H.S.; Dong, L.H.; et al. U-Pb zircon, Re-Os molybdenite geochronology and $\mathrm{Rb}-\mathrm{Sr}$ geochemistry from the Xiaobaishitou W(-Mo) deposit: Implications for Triassic tectonic setting in eastern Tianshan, NW China. Ore Geol. Rev. 2017, 80, 332-351. [CrossRef] 
4. Sengör, A.M.C.; Natalin, B.A.; Burtman, V.S. Evolution of the Altaid tectonic collage and Paleozoic crustal growth in Eurasia. Nature 1993, 364, 299-307. [CrossRef]

5. Gao, J.; Klemd, R.; Qian, Q.; Zhang, X.; Li, J.; Jiang, T.; Yang, Y. The collision between the Yili and Tarim blocks of the Southwestern Altaids: geochemical and age constraints of a leucogranite dike crosscutting the HP-LT metamorphic belt in the Chinese Tianshan Orogen. Tectonophysics 2011, 499, 118-131. [CrossRef]

6. Sillitoe, R.H. A plate tectonic model for the origin of porphyry copper deposits. Econ. Geol. 1972, 67, $184-197$. [CrossRef]

7. Pirajno, F. Hydrothermal Processes and Mineral System; Springer: Berlin, Germany, 2009; pp. 1-1250.

8. Pirajno, F. The Geology and Tectonic Settings of China's Mineral Deposits; Springer: Berlin, Germany, 2013; pp. 1-679.

9. Mao, S.D.; Chen, Y.J.; Zhou, Z.J.; Lu, Y.H.; Guo, J.H.; Qin, Y.; Yu, J.Y. Zircon geochronology and Hf isotope geochemistry of the granitoids in the Yangshan gold field, western Qinling, China: Implications for petrogenesis, ore genesis and tectonic setting. Geol. J. 2014, 49, 359-382. [CrossRef]

10. Zhou, Z.J.; Liu, Z.W.; Qin, Y. Geology, geochemistry and genesis of the Huachanggou gold deposit, western Qinling Orogen, central China. Geol. J. 2014, 49, 424-441. [CrossRef]

11. Chen, Y.J. Progress in the study of Central Asia-type orogenesis-metallogenesis in Northwest China. J. China Univ. Geosci. 2000, 6, 17-22, (In Chinese with English Abstract).

12. Chen, Y.J. Orogenic-type deposits and their metallogenic model and exploration potential. Geol. China 2006, 33, 1181-1196, (In Chinese with English Abstract).

13. Chen, Y.J. Indosinian tectonic setting, magmatism and metallogenesis in Qinling Orogen, central China. Geol. China 2010, 37, 854-865, (In Chinese with English Abstract).

14. Chen, Y.J. The development of continental collision metallogeny and its application. Acta Petrol. Sin. 2013, 29, 1-17, (In Chinese with English Abstract).

15. Chen, Y.J.; Fu, S.G. Gold Mineralization in West Henan, China; Seismological Press: Beijing, China, 1992; pp. 1-234, (In Chinese with English Abstract).

16. Chen, Y.J.; Santosh, M. Triassic tectonics and mineral systems in the Qinling Orogen, central China. Geol. J. 2014, 49, 338-358. [CrossRef]

17. Chen, Y.J.; Santosh, M.; Somerville, I.D.; Chen, H.Y. Indosinian tectonics and mineral systems in China: An introduction. Geol. J. 2014, 49, 331-337. [CrossRef]

18. Abzalov, M. Zarmitan granitoid-hosted gold deposit, Tian Shan Belt, Uzbekistan. Econ. Geol. 2007, 102, 519-532. [CrossRef]

19. Bierlein, F.; Wilde, A. New constraints on the polychronous nature of the giant Muruntau gold deposit from wall-rock alteration and ore paragenetic studies. J. Geol. Soc. Aust. 2010, 57, 839-854. [CrossRef]

20. Chen, Z.L.; Zhou, Y.G.; Han, F.B.; Chen, B.L.; Hao, R.X.; Li, S.B.; Liu, Z.R. Exhumation degree of the Tianshan Range and its implications for ore preservation. J. China Univ. Geosci. 2012, 37, 903-916, (In Chinese with English Abstract).

21. Goldfarb, R.J.; Taylor, R.D.; Collins, G.S.; Goryachev, N.A.; Orlandini, O.F. Phanerozoic continental growth and gold metallogeny of Asia. Gondwana Res. 2014, 25, 48-102. [CrossRef]

22. Li, H.H.; Qiu, R.Z.; Tan, Y.J.; Qi, S.j.; Wang, Q.M.; Wang, K.A.; Wang, H.P.; Wang, J.J.; Yuan, C.H.; Chen, S.D. The Exploration and Development Guidelines of Mineral Resources in the Five Countries in Central Asian; China University of Geosciences Press: Wuhan, China, 2010; pp. 1-207. (In Chinese)

23. Yao, W.G.; Lv, P.R.; Wu, L.; Hong, J.; Yang, B.; Jia, Q.Z.; Li, B.Q. Geological characteristics of dominant mineral resources of the Tianshan Mountains in Kyrgyzstan and their prospecting potential. Geol. Bull. China 2015, 34, 710-725, (In Chinese with English Abstract).

24. Mirkamalov, R.H.; Golovanov, I.M.; Chirikin, V.V.; Phadeicheva, L.P.; Mirkamalova, G.H. Altas of Ore Deposits Models of Uzbekistan; PrintXpress: Tashkent, Uzbekistan, 2011; pp. 1-100.

25. Stein, H.J.; Markey, R.J.; Morgan, J.W.; Hannah, J.L.; Schersten, A. The remarkable Re-Os chronometer in molybdenite: How and why it works. Terra Nova 2001, 13, 479-486. [CrossRef]

26. Conliffe, J.; Selby, D.; Porter, S.J.; Feely, M. Re-Os molybdenite dates from the Ballachulish and Kilmelford igneous complexes (Scottish Highlands): Age constraints for late Caledonian magmatism. J. Geol. Soc. Lond. 2010, 167, 297-302. [CrossRef]

27. Chen, Y.J.; Pirajno, F.; Sui, Y.H. Isotope geochemistry of the Tieluping silver deposit, Henan, China: A case study of orogenic silver deposits and related tectonic setting. Mineral. Depos. 2004, 39, 560-575. [CrossRef] 
28. Chen, Y.J.; Pirajno, F.; Qi, J.P. The Shanggong gold deposit, eastern Qinling Orogen, China: Isotope geochemistry and implications for ore genesis. J. Asian Earth Sci. 2008, 33, 252-266. [CrossRef]

29. Yang, Y.F.; Chen, Y.J.; Li, N.; Mi, M.; Xu, Y.L.; Li, F.L.; Wan, S.Q. Fluid inclusion and isotope geochemistry of the Qian'echong giant porphyry Mo deposit, Dabie Shan, China: A case of $\mathrm{NaCl}$-poor, $\mathrm{CO}_{2}$-rich fluid systems. J. Geochem. Explor. 2013, 124, 1-13. [CrossRef]

30. Zhou, Z.J.; Chen, Y.J.; Jiang, S.Y.; Zhao, H.X.; Qin, Y.; Hu, C.J. Geology, geochemistry and ore genesis of the Wenyu gold deposit, Xiaoqinling gold field, southern margin of North China Craton. Ore Geol. Rev. 2014, 59, 1-20. [CrossRef]

31. Zhou, Z.J.; Chen, Y.J.; Jiang, S.Y.; Hu, C.J.; Qin, Y.; Zhao, H.X. Isotope and fluid inclusion geochemistry and ore genesis of the Qiangma gold deposit, Xiaoqinling gold field, Qinling Orogen, southern margin of North China Craton. Ore Geol. Rev. 2015, 66, 47-64. [CrossRef]

32. Deng, X.H.; Chen, Y.J.; Santosh, M.; Yao, J.M.; Sun, Y.L. Re-Os and Sr-Nd-Pb isotope constraints on source of fluids in the Zhifang Mo deposit, Qinling Orogen, China. Gondwana Res. 2016, 30, 132-143. [CrossRef]

33. Zhou, Z.J.; Chen, Z.L.; Han, F.B.; Han, S.Q.; Wang, Z.X.; Xiao, W.F.; Shen, T.; Wu, J.F. Fluid inclusion and isotope geochemistry of the Atebayue Sb deposit, South Tianshan Orogen, Kyrgyzstan. Geol. J. 2018, 53, 1050-1060. [CrossRef]

34. Gao, J.; Long, L.; Klemd, R.; Qian, Q.; Liu, D.; Xiong, X.; Su, W.; Liu, W.; Wang, Y.; Yang, F. Tectonic evolution of the South Tianshan orogen and adjacent regions, NW China: Geochemical and age constraints of granitoid rocks. Int. J. Earth Sci. 2009, 98, 1221-1238. [CrossRef]

35. Zhang, G.Z.; Xue, C.J.; Chi, G.X.; Liu, J.Y.; Zhao, X.B.; Zu, B.; Zhao, Y. Multiple-stage mineralization in the Sawayaerdun orogenic gold deposit, western Tianshan, Xinjiang: Constraints from paragenesis, EMPA analyses, Re-Os dating of pyrite (arsenopyrite) and U-Pb dating of zircon from the host rocks. Ore Geol. Rev. 2017, 81, 326-341. [CrossRef]

36. Chen, Z.L.; Wang, Z.X.; Han, F.B.; Zhang, W.G.; Zhang, Q.; Zhou, Z.J.; Wang, X.H.; Xiao, W.F.; Han, S.Q.; $\mathrm{Yu}$, X.Q.; et al. Late Cretaceous-Cenozoic uplift, deformation, and erosion of the SW Tianshan Mountains in Kyrgyzstan and Western China. Int. Geol. Rev. 2017, 60, 1-19. [CrossRef]

37. Seltmann, R.; Konopelko, D.; Biske, G.; Divaev, F.; Sergeev, S. Hercynian post-collisional magmatism in the context of Paleozoic magmatic evolution of the Tien Shan orogenic belt. J. Asian Earth Sci. 2011, 42, 821-838. [CrossRef]

38. Yakubchuk, A.; Cole, A.; Seltmann, R.; Shatov, V. Tectonic setting, characteristics, and regional exploration criteria for gold mineralization in the Altaid orogenic collage: The Tien Shan province as a key example. Soc. Econ. Geol. Spec. Publ. 2002, 9, 177-201.

39. Markey, R.; Stein, H.; Morgan, J. Highly precise Re-Os dating for molybdenite using alkaline fusion and NTIMS. Tala 1998, 45, 935-946. [CrossRef]

40. Du, A.D.; He, H.L.; Yin, N.W.; Zou, X.Q.; Sun, Y.L.; Sun, D.Z.; Chen, S.Z.; Qu, W.J. Direct dating of molybdenites using the Re-Os geochronometer. Chinese Sci. Bull. 1993, 38, 1319-1320.

41. Ludwig, K.R. User's Manual for Isoplot 3.00: A Geochronological Toolkit for Microsoft Excel; Berkeley Geochronology Center Special Publication: Berkeley, CA, USA, 2003; pp. 1-70.

42. Stein, H.J.; Markey, R.J.; Morgan, J.W.; Selby, D.; Creaser, R.A.; McCuaig, T.C.; Behn, M. Re-Os Dating of Boddington Molybdenites, SW Yilgarn: Two Au Mineralization Events. AGSO-Geoscience Australia, Record 37. 2001, pp. 469-471. Available online: https://pdfs.semanticscholar.org/2db8/ 8466818aa6fe5e71fdc8845bb889b8887c7d.pdf?_ga=2.109284997.1685928020.1567236989-838078150. 1553161399 (accessed on 31 August 2019).

43. Chen, Y.J.; Wang, P.; Li, N.; Yang, Y.F.; Pirajno, F. The collision-type porphyry Mo deposits in Dabie Shan, China. Ore Geol. Rev. 2017, 81, 405-430. [CrossRef]

44. Li, N.; Chen, Y.J.; Santosh, M.; Yao, J.M.; Sun, Y.L.; Li, J. The 1.85 Ga Mo mineralization in the Xiong'er Terrane, China: Implications for metallogeny associated with assembly of the Columbia supercontinent. Precambrian Res. 2011, 186, 220-232. [CrossRef]

45. Yang, Y.F.; Wang, P. Geology, geochemistry and tectonic settings of molybdenum deposits in southwestern China: A review. Ore Geol. Rev. 2017, 81, 965-995. [CrossRef]

46. Wu, Y.S.; Chen, Y.J.; Zhou, K.F. Mo deposits in Northwest China: Geology, geochemistry, geochronology and tectonic setting. Ore Geol. Rev. 2017, 81, 641-671. [CrossRef] 
47. Zheng, Y.; Cai, X.; Ding, Z.J.; Cawood, P.A.; Yue, S.W. Geology, geochronology and isotopic geochemistry of the Xiaoliugou W-Mo ore field in the Qilian Orogen, NW China: Case study of a skarn system formed during continental collision. Ore Geol. Rev. 2017, 81, 575-586. [CrossRef]

48. Hoefs, J. Stable Isotope Geochemistry, 6th ed.; Springer-Verlag: Berlin/Heidelberg, Germany, 2009; pp. 48-54.

49. Chen, H.Y.; Chen, Y.J.; Baker, M.J. Evolution of ore-forming fluids in the Sawayaerdun gold deposit in the Southwestern Chinese Tianshan metallogenic belt, Northwest China. J. Asian Earth Sci. 2012, 49, 131-144. [CrossRef]

50. Chen, H.Y.; Chen, Y.J.; Baker, M.J. Isotopic geochemistry of the Sawayaerdun orogenic-type gold deposit, Tianshan, northwest China: Implications for ore genesis and mineral exploration. Chem. Geol. 2012, 310-311, 1-11. [CrossRef]

51. Xue, C.J.; Zhao, X.B.; Mo, X.X.; Chen, Y.C.; Dong, L.H.; Gu, X.X.; Zhang, Z.C.; Nurtaev, B.; Pak, N.; Li, Z.D.; et al. Tectonic-metallogenic evolution of western Tianshan giant Au-Cu-Zn-Pb metallogenic belt and prospecting orientation. Acta Geol. Sin. 2014, 88, 2490-2531, (In Chinese with English Abstract).

52. Mörelli, R.; Creaser, R.A.; Seltmann, R.; Stuart, F.M.; Selby, D.; Graupner, T. Age and source constraints for the giant Muruntau gold deposit, Uzbekistan, from coupled Re-Os-He isotopes in arsenopyrite. Geology 2007, 35, 795-798. [CrossRef]

53. Zhao, R.F.; Yang, J.G.; Wang, M.C.; Yao, W.G. The study of metallogenic geologic setting and prospecting potential evaluation in Southwestern Tianshan Mountains. Northwest. Geol. 2002, 35, 101-121, (In Chinese with English Abstract).

54. Li, H.Q.; Chen, F.W. Isotopic Geochronology of Regional Mineralization in Xinjiang, China; Geological Publishing House: Beijing, China, 2004; pp. 1-391, (In Chinese with English Abstract).

55. Xiao, W.J.; Zhang, L.C.; Qin, K.Z.; Sun, S.; Li, J.L. Paleozoic accretionary and collisional tectonics of the eastern Tianshan (CHINA): Implications for the continental growth of Central Asia. Am. J. Sci. 2004, 304, 370-395. [CrossRef]

56. Xiao, W.J.; Han, C.M.; Yuan, C.; Chen, H.L.; Sun, M.; Lin, S.F.; Li, Z.L.; Mao, Q.G.; Zhang, J.E.; Sun, S.; et al. The unique Carboniferous-early Permian tectonic-metallogenic framework of Northern Xinjiang (NW China): Constraints for the tectonics of the southern Paleoasian Domain. Acta Petrol. Sin. 2006, 22, 1062-1076, (In Chinese with English Abstract).

57. Solomovich, L.I. Post collisional magmatism in the South Tien Shan Variscan orogenic belt, Kyrgyztan: Evidence for high-temperature and high-pressure collision. J. Asian Earth Sci. 2007, 30, 142-153. [CrossRef]

58. Konopelko, D.; Biske, G.; Seltmann, R.; Eklun, O.; Belyatsky, B. Hercynian postcollisional A-type granites of the Kokshaal Range, Southern Tien Shan. Lithos 2007, 97, 140-160. [CrossRef]

59. Brookfield, M.E. Geological development and Phanerozoic crustal accretion in the western segment of the southern Tien Shan (Kyrgyzstan, Uzbekistan and Tajikistan). Tectonophysics 2000, 328, 1-14. [CrossRef]

60. Zhang, L.F.; Ai, Y.L.; Li, X.P.; Rubatto, D.; Song, B.; Williams, S.; Song, S.G.; Ellis, D.; Liou, J.G. Triassic collision of western Tianshan orogenic belt, China: Evidence from SHRIMP U-Pb dating of zircon from HP/UHP eclogitic rocks. Lithos 2007, 96, 266-280. [CrossRef]

61. Zhang, L.F.; Ai, Y.L.; Song, S.G.; Liou, J.; Wei, C.J. A brief review of UHP meta-ophiolitic rocks, Southwestern Tianshan, Western China. Int. Geol. Rev. 2007, 49, 811-823. [CrossRef]

62. Kempe, U.; Seltmann, R.; Graupner, T.; Wall, V.J.; Matukov, D.; Sergeev, S. SHRIMP U-Pb zircon dating of Hercynian granite magmatism in the Muruntau gold district (Uzbekistan). In Proceedings of the Interim International Association on the Genesis of Ore Deposits Conference, Vladivostok, Russia, 1-20 September 2004; pp. 210-213, (Abstracts).

63. Nenakhov, V.M.; Ivanikov, V.V.; Kuznetsov, L.V. Osobennosty Izucheniya I Kartirovaniya Kollisionnikh Granitoidov (the Study and Mapping of the Collisional Granitoids); Roscomnedra Press: Moskow, Russian, 1992; pp. 1-100. (In Russian)

64. Solomovich, L.I.; Trifonov, B.A. Postcollisional granites in the South Tien Shan Variscan collisional belt, Kyrgyzstan. J. Asian Earth Sci. 2002, 21, 7-21. [CrossRef]

65. Mao, J.W.; Konopelko, D.; Seltmann, R.; Lehmann, B.; Chen, W.; Wang, Y.T.; Eklund, O.; Usubaliev, T. Postcollisional age of the Kumtor gold deposit and timing of Hercynian events in the Tien Shan, Kyrgyzstan. Econ. Geol. 2004, 99, 1771-1780. [CrossRef] 
66. Long, L.L.; Gao, J.; Qian, Q.; Xiong, X.M.; Wang, J.B.; Wang, Y.W.; Wang, L.J. Geochemistry and SHRIMP zircon $\mathrm{U}-\mathrm{Pb}$ age of post-collisional granites in the southwest Tianshan Orogenic Belt of China: examples from the Heiyingshan and Laohutai plutons. Acta Geol. Sin. 2008, 82, 415-424.

67. Wang, C.; Liu, L.; Luo, J.H.; Che, Z.Z.; Teng, Z.H.; Cao, X.D.; Zhang, J.Y. Late Paleozoic post-collisional magmatism in the Southwestern Tianshan orogenic belt, take the Baleigong pluton in the Kokshal region as an example. Acta Petrol. Sin. 2007, 23, 1830-1840, (In Chinese with English Abstract).

68. Huang, H.; Wang, T.; Qin, Q.; Tong, Y.; Guo, L.; Zhang, L.; Hou, J.Y.; Song, P. Geochronology and zircon Hf isotope of Baleigong granitic pluton in the western part of the South Tianshan Mountains: Petrogenesis and implications for tectonic evolution. Acta Petrol. Mineral. 2015, 34, 971-990, (In Chinese with English Abstract).

69. Huo, H.L.; Chen, Z.L.; Zhang, Q.; Han, F.B.; Zhang, W.G.; Tang, Y.W. Chronological constraints on late Paleozoic collision in the southwest Tianshan orogenic belt, China: Evidence from the Baleigong granite. Acta Geol. Sin. accepted.

70. Soloviev, S.G.; Kryazhev, S.G. Magmatic-hydrothermal evolution at the Lyangar redox-intermediate tungsten-molybdenum skarn deposit, western Uzbekistan, Tien Shan: Insights from igneous petrology, hydrothermal alteration, and fluid inclusion study. Lithos 2018, 316-317, 154-177. [CrossRef]

71. De Grave, J.D.; Glorie, S.; Ryabinin, A.; Zhimulev, F.; Buslov, M.M.; Izmer, A.; Elburg, M.; Vanhaecke, F.; Van den haute, P. Late Palaeozoic and Meso-Cenozoic tectonic evolution of the southern KyrgyzTien Shan: Constraints from multi-method thermochronology in the Trans-Alai, Turkestan-Alai segment and the southeastern Ferghana Basin. J. Asian Earth Sci. 2012, 44, 149-168. [CrossRef]

72. Han, B.F.; He, G.Q.; Wang, X.C.; Guo, Z.J. Late Carboniferous collision between the Tarim and Kazakhstan-Yili terranes in the western segment of the South Tian Shan Orogen, Central Asia, and implications for the Northern Xinjiang, western China. Earth Sci. Rev. 2011, 109, 74-93. [CrossRef]

(C) 2019 by the authors. Licensee MDPI, Basel, Switzerland. This article is an open access article distributed under the terms and conditions of the Creative Commons Attribution (CC BY) license (http://creativecommons.org/licenses/by/4.0/). 